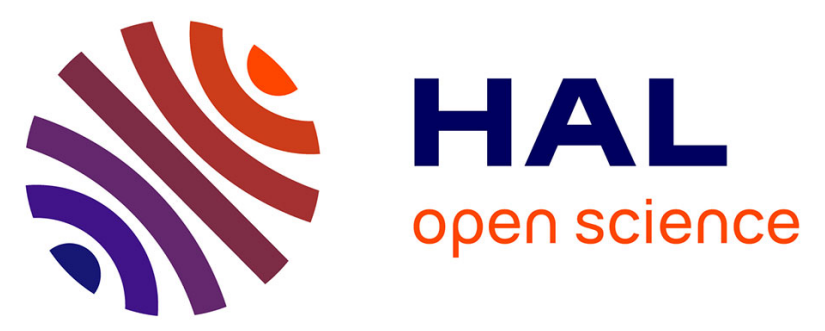

\title{
Flexible Ethanol Production: Energy from Sugarcane Bagasse Might Help the Sustainability of Biofuels
}

\author{
Marcelo Kenji Shibuya, Irenilza De Alencar Näas, Mario Mollo Neto
}

\section{To cite this version:}

Marcelo Kenji Shibuya, Irenilza De Alencar Näas, Mario Mollo Neto. Flexible Ethanol Production: Energy from Sugarcane Bagasse Might Help the Sustainability of Biofuels. IFIP International Conference on Advances in Production Management Systems (APMS), Sep 2015, Tokyo, Japan. pp.662-669, 10.1007/978-3-319-22756-6_81. hal-01417632

\section{HAL Id: hal-01417632 \\ https://hal.science/hal-01417632}

Submitted on 15 Dec 2016

HAL is a multi-disciplinary open access archive for the deposit and dissemination of scientific research documents, whether they are published or not. The documents may come from teaching and research institutions in France or abroad, or from public or private research centers.
L'archive ouverte pluridisciplinaire HAL, est destinée au dépôt et à la diffusion de documents scientifiques de niveau recherche, publiés ou non, émanant des établissements d'enseignement et de recherche français ou étrangers, des laboratoires publics ou privés. 


\title{
Flexible Ethanol Production: Energy from Sugarcane Bagasse Might Help the Sustainability of Biofuels
}

\author{
Marcelo K. Shibuya ${ }^{1}$, Irenilza de A. Näas ${ }^{1}$, Mario Mollo Neto ${ }^{2}$ \\ ${ }^{1}$ Paulista University-UNIP, Graduate Program in Production Engineering, Dr. Bacelar St. \\ 1212, São Paulo, Brazil \\ \{marcelo.shibuya@gmail.com, irenilza@gmail.com \} \\ ${ }^{2}$ UNESP - Campus Tupã, Domingos da Costa Lopes St., Tupã, Brazil \\ \{mariomollo@gmail.com\}
}

\begin{abstract}
The ethanol industry in Brazil is going through a period of stagnation, resulting in the reduction of ethanol supply. The ethanol for automotive purposes may be anhydrous, which is used as an anti-detonating additive to gasoline; and hydrated ethanol, which can be used in the flex-fuel vehicles, which can use the biofuel, gasoline or a mixture of both in any proportion. This study is aimed to analyze the contribution that energy from the sugarcane bagasse could bring to the production of corn ethanol in plants adapted to operate with both sugarcane and the cereal. Therefore, it was considered, the surplus energy from sugarcane biomass and maize availability in the producing region. At the end of the article, the results are discussed by providing an analysis of the application of corn as alternative raw material for the production of ethanol in Brazil.
\end{abstract}

Keywords: Biofuel, Ethanol, Energy Efficiency.

\section{Introduction}

Anhydrous ethanol is the most important additive mixed with gasoline and hydrated ethanol can be used as an alternative fuel for flex-fuel vehicles that may either pure gasoline, hydrated ethanol or a mixture of both in any proportion $[1,2]$. Since 2009, a reduction of hydrous ethanol demand in Brazil began, which rose from 16,471 million cubic meters in this year to the volume of 9,793 million cubic meters in 2013 [3]. Gasoline, on the other hand, was used in the volume of 25,409 million cubic meters in 2009, and trespassing the 39,678 million cubic meters in 2013.

The increase in fossil fuel consumption and the reduction of the biofuel demand is shown by [4] as a period of stagnation and expansion interruption about the sugarcane industry in Brazil. The same authors add that what contributed to this phase of stagnation was the government intervention in gasoline prices, which occurred from 2008 to 2012 to fight inflation rate. This interference has caused the price of commercial 
gasoline to fall to a price lower than the international oil barrel price, affecting the relative price of ethanol and the fossil fuel. Also, there was a decline in productivity in the sugar cane plantation, helping to intensify the crisis in the sector. Still, according to the authors, the reduction ethanol plants expansion and shifting of the biofuel supply, determined the increase in their prices to consumers and thus reduced their consumption.

Brazilian plants of ethanol production are self-sufficient in energy [5], which is one of the competitive advantages of the ethanol produced in the country. Under this approach, the combination of the availability of ethanol plants and surplus energy obtained from sugarcane bagasse and corn production in the same geographic region, corn ethanol would have conditions to be produced. Therefore, as defined by [6], there is a need to adapt these plants to operate with both raw materials. The author indicates that when the industrial plant originally built for processing sugar, starts to process corn it requires an investment of near US\$ 8,5 million.

This article aims to analyze the additional ethanol that could be produced using corn as raw material, and the excess energy obtained from sugarcane bagasse in the plants located in the Midwest of Brazil. In this way, the additional ethanol produced from corn help make the Brazilian ethanol production sustainable. The present study was conducted in this geographic region because it has ethanol production from sugarcane and corn as raw material.

\section{$2 \quad$ Literature Review}

\subsection{Sugarcane ethanol and corn ethanol production in the Midwest of Brazil.}

According to [7], the production of ethanol from sugarcane occurs simultaneously with the sugarcane harvest, that is, from March to December of each year. The author [3] define that the higher volumes of biofuels are produced in the intermediate harvest months, from July to September. This feature of production makes ethanol prices higher to consumers, in the offseason of sugarcane and start the production cycle, when the biofuel stocks tend to be at lower levels [3].

Brazilian production of ethanol from the sugarcane and the use of flex-fuel vehicles are world references in renewable energy [3]. The same author adds that ethanol production has promoted the rural development, diversification of energy sources, reduction of dependence on imported oil, and especially the reduction of air pollution and greenhouse gasses. The regional production of ethanol from sugarcane for the year 2013 is presented in Table 1.

Brazil is a pioneer in the production of sugarcane ethanol, has been successful in overcoming the initial challenges for developing this fuel, making efficient use of agricultural production technologies, modern management practices of crop, and the use of bagasse after grinding to generate heat and electricity for the production of ethanol [8]. Two crops of corn are harvested in Brazil per year [15]. The first crop has a cycle from October of one year to April of the following year; and the second crop (also known as a winter crop), occurs from January to July of the same year. The second crop of corn alternates the soil with soybeans. The potential of increasing 
production of corn to 72.239 million tons, in case of using all soybean planting area, [9]. The same author adds that due to high costs of transporting the surplus production from the Midwest, the production of second maize crop of this region is economically attractive only in the periods of high international prices. These factors make the second maize is a viable alternative as raw material for ethanol production in this region.

Table 1. Brazilian regional production of ethanol (source: [3])

\begin{tabular}{lcc}
\hline Region & Production 2013 & Production Percentage \\
\hline North & 253.61 & $0.91 \%$ \\
Northeast & $1,703.67$ & $6.13 \%$ \\
Southeast & $17,167.74$ & $61.74 \%$ \\
South & $1,475.83$ & $5.31 \%$ \\
Midwest & $7,207.75$ & $25.92 \%$ \\
Brazil in Total & $27,808.59$ & $100 \%$ \\
\hline
\end{tabular}

Table 2 shows the production details in the Midwest region of Brazil. The states of Mato Grosso (MT), Mato Grosso do Sul (MS), and Goiás (GO) composes the region. Table 2 also indicates the respective amounts of ethanol plants installed, the average days of operation of the plants, and the quantities harvested in the second corn crop in 2013.

Table 2. Number of plants, average days of operation and the second corn crop (source: $[3,15$, 16])

\begin{tabular}{ccccc}
\hline State & $\begin{array}{c}\text { Quant. } \\
\text { Plants }\end{array}$ & $\begin{array}{l}\text { Average days } \\
\text { of operation } \\
\text { per year }\end{array}$ & $\begin{array}{l}\text { Sugarcane ethanol pro- } \\
\text { duced in the crop of } \mathbf{2 0 1 4} \\
\left(\mathbf{1 0}^{\mathbf{6}} \mathbf{~ m}^{\mathbf{3}}\right)\end{array}$ & $\begin{array}{l}\text { Second corn crop } \\
\text { in 2012 } \\
\left(\mathbf{1 0}^{\mathbf{6}} \text { ton }\right)\end{array}$ \\
\hline MS & 23 & 222 & 2248.37 & $7,451.1$ \\
GO & 36 & 183 & 3871.93 & $4,816.9$ \\
MT & 9 & 173 & 1087.46 & $19,357.8$ \\
\hline
\end{tabular}

\subsection{Corn Ethanol: the American experience and perspectives for production in Brazil.}

In the United States, the ethanol produced from corn is currently the dominant biofuel, using $30 \%$ of the total corn production in the country. According to [10], two processes are used to produce ethanol from corn: dry or wet milling. Milling ethanol by the wet method provides a greater amount of by-products such as corn oil, carbon dioxide gas, starch, and approximately 440 liters of anhydrous ethanol per ton of corn. Furthermore, ethanol production by the dry process has attracted major interest by producers, for providing a higher amount of biofuel production $(460 \mathrm{~L}$ of anhydrous ethanol plus $380 \mathrm{~kg}$ DDGS-Distillers Dried Grains with Solubles) per ton of processed corn. 
One of the disadvantages of the production of ethanol from corn from corn is the impossibility of total utilization of biomass corn as a source of power generation, as occurs with the bagasse from sugarcane. According to $[7,11]$, the corn harvest generates straw, stem, leaves and cobs left $\mathrm{n}$ the field to preserve fertility and soil moisture. Thus, in the US, other energy sources are used, such as natural gas or shale gas. Regarding the characteristics of the raw materials used for ethanol production, sugarcane should be ground and processed within hours of harvest otherwise there is the loss of sucrose and, therefore, the reduction of the ethanol or sugar production [9]. On the other hand, corn does not undergo this problem and may be stored for long periods.

Data from December 2013 to April 2014 [12] from two plants in the state of Mato Grosso (MT) converted to operate simultaneously with sugarcane and corn, showed a production of 0.37 million cubic meters of ethanol from corn. The product used was the leftover of the winter crop in that state. It should be noted that the use of grain for ethanol production occurred precisely in the off-season of sugarcane, which occurs from December to April when the plants are interrupted for lack of sugarcane.

It was recently reported [12] the income earned by the plants installed in the state of Mato Grosso, with $0.352 \mathrm{~m}^{3}$ of ethanol per ton of corn and $169.5 \mathrm{~kg}$ of DDGS per ton of corn. An important point to note, especially when analyzing the sustainability and competitiveness of ethanol production, is the consumption and how to obtain the energy used in industrial steps. In a published study [13] the authors state that the industrial processing of a ton of sugarcane, to obtain $85 \mathrm{~L}$ of ethanol consumes 1641.56 MJ, while processing a ton of corn produces $352 \mathrm{~L}$ of ethanol and consumes 3882.39 MJ of energy. These data become important when placed in the analysis of sugarcane bagasse that is the main source of supply of thermal and electric energy for ethanol production in the plants. According to [14], processing a ton of sugarcane generates $276 \mathrm{~kg}$ of bagasse with potential energy of $2503.71 \mathrm{MJ}$, and when the harvest is mechanized, it can obtain the amount of $165 \mathrm{~kg}$ per ton of cane straw harvested, which has the potential energy of 2143.64 MJ.

Considering the losses of $21 \%$ in the conversion of the burning of sugarcane bagasse or straw, to obtain steam in the sugarcane plants [14], one can estimate that, to process a ton of sugarcane there is a brute availability of $2503.71 \mathrm{MJ}$ of energy through bagasse, and consume of 525.78 MJ in the process of obtaining ethanol, with an extra amount of $336.37 \mathrm{MJ}$, which could be used to process corn for the production of ethanol.

\section{$3 \quad$ Methodology}

In this article, ethanol production potential in the Midwest region of Brazil was estimated through simulation, taking into account the use of sugarcane during their respective harvest and corn during the off season from sugarcane. The data used in the study was obtained from $[3,15,16]$. From these data, we estimated the potential contribution that corn ethanol could bring to the biofuel supply in the Midwest of Brazil. Calculations were performed in two different scenarios. In the first, the production of sugarcane ethanol was considered, in volumes achieved in 2013, and the excess energy from sugarcane bagasse being used for the production of corn ethanol. In this 
case, the limit of corn ethanol production could come from energy availability or availability of cereal in each analyzed state. The determinist simulation was adopted, and the production process variability was not considered (such as raw material quality).

In the second scenario use of energy from sugarcane bagasse and straw as energy source for obtaining the volume of ethanol was considered. In relation to the volume of corn used for ethanol production, it was necessary to consider between 1) the amount of corn processable due to the availability of energy; 2) the amount of grain from the harvest of the second crop; and 3) the amount of corn required for the production of 120 days of ethanol, having as a basis, the average volume obtained from the sugarcane.

The simulation of scenarios 1 and 2 are described by equations 1, 2, 3 and 4 .

$$
D_{E c}=\frac{V_{e}}{0,085} \times 2.503
$$

Where: $\mathrm{D}_{\mathrm{Ec}}=$ energy available from the sugarcane bagasse (in $\mathrm{MJ}$ ), $\mathrm{V}_{\mathrm{e}}=$ volume of produced ethanol $\left(\mathrm{m}^{3}\right), 0,085=$ volume of ethanol $\left(\mathrm{m}^{3}\right)$ produced per ton of sugarcane, $2.503=$ Amount of energy obtained from the bagasse of 1 ton of sugarcane in MJ.

$$
D_{E p}=\frac{V_{e}}{0,085} \times 2.134
$$

Where: $\mathrm{D}_{\mathrm{Ep}}=$ energy available from the sugarcane bagasse (in $\left.\mathrm{MJ}\right), \mathrm{V}_{\mathrm{e}}=$ volume of produced ethanol $\left(\mathrm{m}^{3}\right), 0.085=$ volume of ethanol $\left(\mathrm{m}^{3}\right)$ produced per ton of sugarcane, 2,503 = Amount of energy obtained from straw per ton of sugarcane in MJ.

$$
E_{e x}=D_{e} x 0.79-E_{c}
$$

Where: $E_{\mathrm{ex}}=$ Excess energy available to the industrial processing of corn (in $\mathrm{MJ}$ ), $D_{e}=$ Availability of energy from sugarcane bagasse (in MJ), $E_{c}=$ energy used for the processing of sugarcane ethanol production (in $\mathrm{MJ}$ ).

$$
E_{M}=\frac{E_{e x}}{E_{p m}} \times 0,350
$$

Where: $E_{M}=$ Volume of ethanol obtained from corn $\left(\right.$ in $\left.\mathrm{m}^{3}\right), \mathrm{E}_{\mathrm{ex}}=$ Excess energy Available for the processing of corn ethanol (in $\mathrm{MJ}$ ), $\mathrm{E}_{\mathrm{pm}}=$ Energy necessary for the processing of 1 ton of corn (in MJ), 0,350 = Volume of ethanol obtained (in $\mathrm{m}^{3}$ ) in the processing of 1 ton of corn.

\section{$4 \quad$ Results and Discussion}

Tables 3 and 4 show the results obtained from the simulations performed. On the first scenario, it was possible to estimate 2,537.9 cubic meters of ethanol from corn, 
an additional $35.21 \%$ of the production of sugarcane ethanol. Note that in bold are the values of corn considered in the processing of ethanol.

Table 3. Results of the simulation for scenario 1

\begin{tabular}{|c|l|c|c|c|c|}
\hline State & $\begin{array}{l}\text { Second } \\
\text { corn crop - } \\
\text { ref. 2013 } \\
\text { (ton) }\end{array}$ & $\begin{array}{l}\text { Processable corn due } \\
\text { to excessive energy } \\
\text { available (ton) }\end{array}$ & $\begin{array}{l}\text { Excess } \\
\text { Energy } \\
\left(\mathbf{1 0}^{\wedge} \mathbf{6}\right. \\
\mathbf{M J})\end{array}$ & $\begin{array}{l}\text { Sugarcane } \\
\text { ethanol } \\
\left(\mathbf{m}^{\mathbf{3}}\right)\end{array}$ & $\begin{array}{l}\text { Corn etha- } \\
\text { nol }\left(\mathbf{m}^{\mathbf{3}}\right)\end{array}$ \\
\hline MS & $7,451,100$ & $\mathbf{2 , 2 9 1 , 7 5 5}$ & 8,897 & $2,248,370$ & 802,114 \\
\hline GO & $4,816,900$ & $\mathbf{3 , 9 4 6 , 6 4 3}$ & 15,322 & $3,871,930$ & $1,355,176$ \\
\hline MT & $19,357,800$ & $\mathbf{1 , 1 0 8 , 4 4 4}$ & 4,303 & $1,087,460$ & 380,611 \\
\hline & & Total & & $7,207,760$ & $2,537,901$ \\
\hline
\end{tabular}

In scenario 2, the use of available energy (from the former originator of sugarcane bagasse and straw), the volume of processable corn with the available energy, the daily amount of processable corn, and the corn harvested in 2013 crop were considered. In Table 2, in bold, there are defined the amount of corn that were considered for the production of ethanol, according to the conditions stated in methodology. Note that in this scenario, it was possible to obtain an additional $66.08 \%$ compared to ethanol obtained from sugarcane.

The results of the study showed that ethanol produced from the cereal can give a large share of contribution to the increase of biofuel supply in Brazil. Thus, the deficit of biofuel announced by [4] would be minimized, giving conditions for the sector to re-grow with increasing demand for biofuel

As defined by $[6,9]$, the present study considered the corn processed in off-season periods of sugarcane, that is, from January to April, when the ethanol processing plants are interrupted for lack of cane sugar. Thus, there is less inactivity in power plants, considering that the yield of sugarcane ethanol is produced from this raw material and other periods can use as a cereal raw material.

Table 4. Results of the simulation for scenario 2.

\begin{tabular}{|c|c|c|c|c|c|c|}
\hline State & $\begin{array}{l}\text { Second } \\
\text { corn crop } \\
\text { - ref. } 2013 \\
\text { (ton) }\end{array}$ & $\begin{array}{l}\text { Processable } \\
\text { corn due to } \\
\text { excessive } \\
\text { energy } \\
\text { available } \\
\text { (ton) }\end{array}$ & $\begin{array}{l}\text { Processable } \\
\text { corn in } 120 \\
\text { days of } \\
\text { production. } \\
\text { (ton) }\end{array}$ & $\begin{array}{l}\text { Excess } \\
\text { Energy } \\
\left(10^{\wedge} 6\right. \\
\text { MJ) }\end{array}$ & $\begin{array}{l}\text { Sugar- } \\
\text { cane eth- } \\
\text { anol }\left(\mathbf{m}^{3}\right)\end{array}$ & $\begin{array}{l}\text { Corn } \\
\text { ethanol } \\
\left(\mathbf{m}^{3}\right)\end{array}$ \\
\hline MS & $7,451,100$ & $13,829,704$ & $6,252,671$ & 53,692 & $2,248,370$ & $2,188,435$ \\
\hline GO & $4,816,900$ & $23,816,208$ & $3,175,978$ & 92,464 & $3,871,930$ & $1,111,592$ \\
\hline MT & $\begin{array}{c}19,357,80 \\
0\end{array}$ & $6,688,957$ & $4,180,598$ & 25,969 & $1,087,460$ & $1,463,209$ \\
\hline \multicolumn{5}{|c|}{ Total } & $7,207,760$ & $4,763,237$ \\
\hline
\end{tabular}


Another observation to be added is related to the sale price of corn ethanol by producing plants. As the production of corn ethanol is practiced in the offseason of sugarcane, as cited by [3], producers can benefit from it, and have more attractive prices in marketing their products.

Concerning the energy needed for producing ethanol from corn, the current study showed that the use of the excess sugarcane bagasse is possible to increase in $35.21 \%$ the ethanol production; and the use of excess sugarcane bagasse and straw, can increase $66.08 \%$. Both studies considered the regional cereal availability, availability of energy and the maximum production by the State plants. These results show that the conversion of energy plants to operate with corn can help the energy efficiency of production facilities to increase production of biofuels with greater use of excess biomass. This energy efficiency is a competitive advantage of the plants prepared to operate with the two raw materials in relation to the typical American plants, as defined by $[7,11]$ which require external energy for processing corn.

Finally, we must add a note about the storage aspects of the two raw materials. As defined by [9], sugarcane must be processed hours after harvest, and corn can be stored for a longer period. The plants adapted to operate with both raw materials can benefit from this feature, because could be used to meet the agricultural productivity fluctuations of sugarcane, as reported by [4].

\section{Conclusion}

The study showed, for the Midwest region of Brazil, the additional volumes of ethanol that can be produced with the use of corn-producing plants previously adapted from only processing sugarcane ethanol. These results were obtained by simulation, considering the use of biomass from sugarcane. From the results obtained, it was possible to prove the energetic feasibility that the plants have to adapt to the operation with corn as raw material. Also to increasing the production, it is concluded in the present study that the use of corn can reduce inactivity of the ethanol plants in the off periods of sugarcane, using corn as raw material. Another benefit of the use of corn would be its use to minimize the effects of fluctuations in the production of sugarcane due to climatic factors. The results of the current study could be useful for both producers and policy makers. For producers, the study may predict the amount of ethanol that might be increased due to the addition of corn in the process. For policy makers, the study may subsidize information for the political decision-making process in biofuels in the country.

In future research, detailed studies could be carried out considering the monthly variation in the supply of sugarcane and the use of corn as an instrument to maintain the production in volumes of ethanol.

\section{References}

1. Coelho, S.T.; GoldemberG, J.; Lucon, O.; Guardabassi, P.; Brazilian Sugarcane Ethanol: Lessons Learned. Energy for Sustainable Development; Volume X, N 2; June 2006. 
2. Freitas, L. C., Kaneko, S.; Ethanol Demand under the Flex Fuel Technology Regime in Brazil.; Energy Economics 33, pg 1146 - 1154. 2011

3. ANP - Agência Nacional do Petróleo, Gás Natural e Biocombustiveis; Anuário Estatístico 2014; Brasília/DF. Disponível em http://www.anp.gov.br/?pg=60983\#Se_o_2; consultado em $05 / 12 / 2014$.

4. Nogueira, L. A. H; Capaz, R. S.; Biofuels in Brazil: Evolution, Achievements and Perspectives on Food Security; Global Food Security 2; pg 117-125; 2013.

5. Dantas, G. A., Legey, L. F. L., Mazzone, A., Energy from Sugarcane Bagasse in Brazil: An Assessment of the Productivity and Cost of Different Technological Routes, Renewable and Sustainable Energy Reviews 21, pg 356-364, 2013.

6. APROSOJA: I Forum Brasileiro de Etanol de Milho e Sorgo; Sorriso - MT (2013).

7. Hofsetz, K; Silva, M. A.; Brazilian Sugarcane Bagasse: Energy and Non-energy consumption; Biomass and Energy 46; pg. 564-573; 2012.

8. Du, X.; Carriquiry, M. A.; Flex Fuel Vehicle Adoption and Dynamics of Ethanol Prices: Lessons from Brazil; Energy Policy 59; pag. 507-512; 2013.

9. BNDES. A Produção do Etanol pela Integração do Milho-Safrinha às Usinas de Cana de Açúcar: Avaliação Ambiental, Econômica e Sugestões de Política. Brasília, 2014.

10. Hettinga, W. G.; Junginger, H. M., Dekker, S. C.; Hoogwijk, M; Mcaloon, A. J.; Hicks, K. B.; Undestanding the Reduction in US Corn Ethanol Production Costs: An Experience Curve Approach; Energy Policy 37; pg 190-203; 2009.

11. Crago, C.L.; Khanna, M.; Barton, J.; Giuliani, E.; Amaral, W.; Competitiveness of Brazilian Sugarcane Ethanol Compared to US Corn Ethanol; Energy Policy 38; pg 7404-7415; 2010.

12. UNICA - União da Indústria da Cana de Açúcar; Relatório Final da Safra 2013-2014, disponível em http://www.unicadata.com.br/listagem.php?idMn=88, access in 11/03/2015.

13. Salla, D. A., Cabello, C.; Análise Energética na Produção de Etanol de Mandioca, Cana de Açúcar e Milho. Revista Energia na Agricultura, Botucatu, Vol. 25, no 2; p. 32 a 53.

14. Lamonica, H. M., Produção de Vapor e Eletricidade - A Evolução do Setor Sucroalcooleiro, Workshop de Gestão de Energia e Resíduos na Agroindústria Sucroalcooleira, 2007.

15. CONAB; Acompanhamento da Safra Brasileira - Grãos; V1 - Safra 2013/14, Brasília; Dez 2013

16. CONAB; Perfil do Setor do Açúcar e do Álcool no Brasil; Volume 5 - Safra 2011/2012; Brasília; 2013. 